\author{
Okipniuk Volodymyr, \\ Candidate of Juridical Sciences, \\ Associate Professor, Head of the \\ Department of the National Academy of \\ the Security Service of Ukraine, \\ Kyiv, Ukraine
}

\title{
BODIES OF THE MGB OF THE UKRSSR AT THE FINAL STAGE OF THE STALINIST TOTALITARIAN REGIME (1946-1953): HISTORICAL AND LEGAL RESEARCH
}

The article deals with the historical and legal research on the development of the legal status and activities of the organs of the Moscow City Medical Service in the postwar period. It was established that under the influence of a number of external and internal political factors, changes in the legal status, organizational structure and enforcement activities of the Soviet bodies of state security in Ukraine took place. In the conditions of the beginning of the Cold War, the party-Soviet leadership of the USSR greatly expanded the powers of the established MGB of the USSR in virtually all spheres of the operation of the special service, which strengthened their punitive direction.

Based on the analysis of legal acts, it was determined that the priority directions of the activity of the Soviet secret services in Ukraine at the final stage of the totalitarian regime were: counteraction to the special services of the United States, Britain and their NATO allies, the struggle with the Ukrainian nationalist movement, clandestine religious organizations, the provision of state security, political search, protection of public order in transport, search for agents of former Nazi punitive bodies, protection of state secrets, detention of places of imprisonment, pre-casting correspondence, external observation and operative installation, implementation of 
radio-intelligence measures, protection of state borders and provision of public safety and special government communications, etc.

The organs of the MGB of the UkrSSR were endowed with many functions that were not peculiar to them, which complicated their activities. At the same time, the extension of the powers of the organs of the Bolshevik Military Bureau of the UkrSSR led to total control over all spheres of the state and public life of the republic, the formation of the regime of "iron curtain", contributed to the development of large-scale repressions against the general population and a massive violation of fundamental human and civil rights.

Key words: MDB, soviet state security bodies, stalinist totalitarian regime.

\section{REFERENCES}

1. Zaitsiev L.O. (2014) Sudoustrii i sudochynstvo v umovakh voiennoho stanu (1941-1946 rr.). "Judiciary and justice in martial law (1941-1946)". The Judiciary in Ukraine: Historical Origins, Patterns, Features of Development. Kyiv : «Naukova dumka». P. 409-424. [in Ukrainian].

2. Haluzevyi derzhavnyi arkhiv Sluzhby bezpeky Ukrainy. "Sectoral State Archive of the Security Service of Ukraine”. F. 9. Ref. 17 (USSR). [in Ukrainian].

3. Haluzevyi derzhavnyi arkhiv Sluzhby bezpeky Ukrainy. "Sectoral State Archive of the Security Service of Ukraine”. F. 9. Ref. 18 (USSR). [in Ukrainian].

4. Okipniuk V.T. (2018) Radianski orhany viiskovoi kontrrozvidky v Ukraini na pochatkovomu etapi «kholodnoi viiny» (1946-1953). "Soviet counterintelligence bodies in Ukraine in the early stages of the Cold War (1946-1953)". Scientific notes of the Institute of Legislation of the Verkhovna Rada of Ukraine. No. 5. P. 7-13. [in Ukrainian].

5. Petrov N.V. (2010) Kto rukovodyl orhanamy hosbezopasnosty, 1941-1954. "Who led the state security organs, 1941-1954": reference book. Int. about, RGASPI, GARF, CA FSB of Russia. M .: Memorial Island; "Links".1008 p. [in Russian].

6. Haluzevyi derzhavnyi arkhiv Sluzhby bezpeky Ukrainy. "Galuzey Sovereign Archiv Service of the Bezpeki of Ukraine”. F. 9. Ref. 123. [in Ukrainian]. 
7. Kokurin A.I. , Petrov N.V. (2003) Lubianka: Orhany VChK-OHPU-NKVDNKHB-MHB-KHB. 1917-1991. "Bodies of the Cheka-OGPU - NKVD - NKGB MGB - KGB”. 1917-1991. Directory. ed. Acad. A.N. Yakovleva. M.: MFD.768 p. 646. [in Ukrainian].

8. Haluzevyi derzhavnyi arkhiv Sluzhby bezpeky Ukrainy. "Sectoral State Archive of the Security Service of Ukraine”. F. 9. Ref. 159. [in Ukrainian].

9. Haluzevyi derzhavnyi arkhiv Sluzhby bezpeky Ukrainy. "Sectoral State Archive of the Security Service of Ukraine”. F. 9. Ref. 679-702. [in Ukrainian].

10. Haluzevyi derzhavnyi arkhiv Sluzhby bezpeky Ukrainy. "Sectoral State Archive of the Security Service of Ukraine”. F. 9. Ref. 118. [in Ukrainian].

11. Haluzevyi derzhavnyi arkhiv Sluzhby bezpeky Ukrainy. "Sectoral State Archive of the Security Service of Ukraine”. F. 9. Ref. 119. [in Ukrainian].

12. Haluzevyi derzhavnyi arkhiv Sluzhby bezpeky Ukrainy. "Sectoral State Archive of the Security Service of Ukraine”. F. 21. Op.1. Ref. 17. [in Ukrainian].

13. Haluzevyi derzhavnyi arkhiv Sluzhby bezpeky Ukrainy. "Sectoral State Archive of the Security Service of Ukraine”. F. 9. Ref. 144. [in Ukrainian].

14. Okipniuk V.T. (2018) Slidcha diialnist orhaniv derzhavnoi bezpeky URSR (seredyna 1930-kh - pochatok 1950-kh rokiv). "Investigative Activity of the USSR State Security Authorities (mid 1930s - early 1950s)": historical and legal analysis. Journal of the Kyiv University of Law. No. 3. P. 41-45. [in Ukrainian].

15. Haluzevyi derzhavnyi arkhiv Sluzhby bezpeky Ukrainy. "Sectoral State Archive of the Security Service of Ukraine”. F. 21. Ref. 124. [in Ukrainian].

16. Haluzevyi derzhavnyi arkhiv Sluzhby bezpeky Ukrainy. "Sectoral State Archive of the Security Service of Ukraine”. F. 21. Ref. 141. [in Ukrainian].

17. Okipniuk V.T. (2018) Yurydychnyi status mists utrymannia zaareshtovanykh v orhanakh derzhavnoi bezpeky URSR (1929-1953 roky): istoryko-pravovyi analiz. "Legal status of places of detention in the security organs of the USSR (1929-1953): a historical and legal analysis". Bulletin of the Penitentiary Association of Ukraine. No. 4 (6). P. 117-124. [in Ukrainian].

18. Haluzevyi derzhavnyi arkhiv Sluzhby bezpeky Ukrainy. "Sectoral State Archive of the Security Service of Ukraine”. F. 9. Ref. 143. [in Ukrainian]. 
19. Okipniuk V.T. (2018) Yurydychne rehuliuvannia zakhystu informatsii z obmezhenym dostupom $\mathrm{v}$ Ukraini $\mathrm{v}$ umovakh totalitarnoho rezhymu: istorykopravovyi analiz. "Legal regulation of protection of information with restricted access in Ukraine under conditions of totalitarian regime: historical and legal analysis". Information security of the person, society, state. No. 2 (24). P. 125-131. [in Ukrainian].

20. Haluzevyi derzhavnyi arkhiv Sluzhby bezpeky Ukrainy. "Sectoral State Archive of the Security Service of Ukraine”. F. 9. Ref. 121. [in Ukrainian].

21. Haluzevyi derzhavnyi arkhiv Sluzhby bezpeky Ukrainy. "Sectoral State Archive of the Security Service of Ukraine”. F. 9. Ref. 122. [in Ukrainian].

22. Tsentralnyi derzhavnyi arkhiv hromadskykh obiednan Ukrainy. "Central State Archive of Public Associations of Ukraine”. F. 1. Op. 16. Sp.60. [in Ukrainian].

23. Tsentralnyi derzhavnyi arkhiv hromadskykh obiednan Ukrainy. "Central State Archive of Public Associations of Ukraine”. F. 1. Op. 16. Sp.68. [in Ukrainian].

24. Haluzevyi derzhavnyi arkhiv Sluzhby bezpeky Ukrainy. "Sectoral State Archive of the Security Service of Ukraine”. F. 9. Ref. 140. [in Ukrainian].

25. Haluzevyi derzhavnyi arkhiv Sluzhby bezpeky Ukrainy. "Sectoral State Archive of the Security Service of Ukraine”. F. 9. Ref. 142. [in Ukrainian].

26. Tsentralnyi derzhavnyi arkhiv hromadskykh obiednan Ukrainy. "Central State Archive of Public Associations of Ukraine”. F. 1. Op. 16. Sp.72. [in Ukrainian].

27. Haluzevyi derzhavnyi arkhiv Sluzhby bezpeky Ukrainy. "Sectoral State Archive of the Security Service of Ukraine”. F. 9. Ref. 158. [in Ukrainian]. 